\title{
Monitoring and evaluation: The missing link in South African municipalities
}

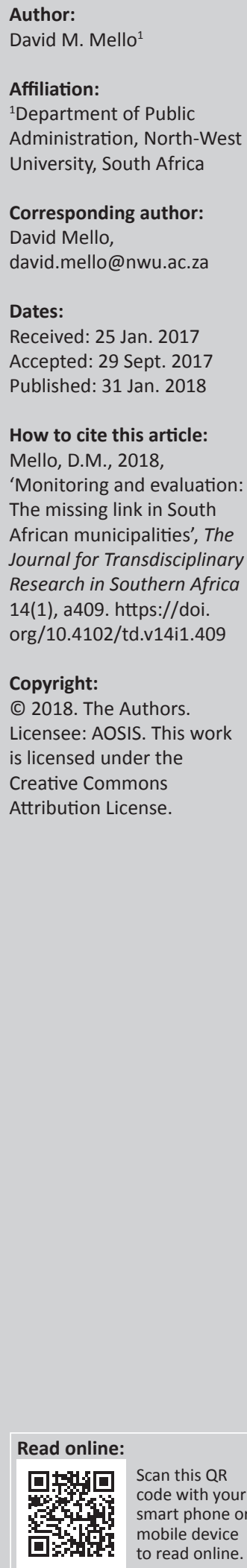

\begin{abstract}
The Auditor-General of South Africa reports for the financial years 2012-2013, 2013-2014 and 2014-2015 paint a gloomy picture of local government performance in some provinces. Many municipalities in South Africa are not performing as expected because of a host of problems that include weaknesses in monitoring and evaluation systems. The study preceding this article was qualitative in nature and focused on the Auditor-General's reports for the 20122013,2013-2014 and 2014-2015 financial years. Main findings of the study are that municipalities that get clean audits have strong oversight systems and leadership. A further inference is that qualifications of councillors, training, time and remuneration are contributing factors to poor oversight by councillors and political structures. The main recommendations were directed at improving civic education in the nomination and election of councillors, pairing underperforming municipalities with best performing municipalities, improving continuing education for councillors and improving the monitoring of interventions and the transitions after interventions.
\end{abstract}

\section{Introduction}

Existing financial resources are seldom enough for municipalities to be able to fulfil their constitutional and legal mandates in South Africa. It is the responsibility of any organ of state, including municipalities, to use their resources efficiently. To achieve this elusive goal, monitoring and evaluation need to be strengthened in all underperforming South African municipalities. This article argues that lack of capacity and poor oversight within and outside municipalities are some of the underlying reasons for poor performance of some municipalities. The article starts with an exposition of the methodology followed by an explanation of the analytical framework as well as an assessment of the state of municipalities in South Africa. Furthermore, the article provides insight into the capacity of municipal councillors to exercise their oversight roles and reflects on time as a critical factor in monitoring and evaluation. Having discussed the capacity of councillors, the article in the penultimate assesses the role of audit and public accounts committees in monitoring and evaluation. Finally, the article arrives at some conclusions and makes recommendations aimed at improving monitoring and evaluation in South African municipalities.

\section{Research methodology}

Researchers have a choice to adopt a variety of methods that include but are not limited to qualitative and quantitative methods in probing a specific problem or area of interest. The study that preceded the compilation of this article was qualitative. The design chosen for this study was the archival design that focuses on secondary data analysis. According to Saunders, Lewis and Thornhill (2009:258-259), secondary data analysis could focus on databases, reports and websites. South African municipalities were the subject of the study. Secondary data sources used in this study were the Auditor-General's reports for the 2012-2013, 2013-2014 and 2014-2015 financial years. Figures from these reports were reanalysed to arrive at specific findings.

\section{Analytical framework for the article}

Bana (2014:640) rightly argues that 'theory without practice is empty and practice without theory is blind'. Bana's statement may sound like a banal rhetoric. However, it is the author's conviction that there should always be some symbiosis between theory and practice. It is for this reason that the discussion in this article is underpinned by public choice theory. Public choice theory encourages one to be sceptical about decisions taken by individual politicians to join politics and the decisions they take while discharging duties in public office. The fundamental question within the context of this theory is whether politicians always act in the best interest of the public as they claim or their individual interest takes precedence in decision-making. 


\section{State of municipalities in South Africa}

A number of South African municipalities are not performing at the level required and expected by law and citizens who foot the bill for the administration of such municipalities. This view is shared by Govender and Reddy (2014:163). This parlous state of affairs is mainly because of a weak system of monitoring and evaluation, the incapacity of councillors and officials to monitor projects and finances. The non-existence of or poorly resourced monitoring and evaluation units adds salt to the wound. Furthermore, this state of affairs becomes a perfect breeding ground for corruption and chronic underspending. A direct consequence has been the spread of service delivery protests that have been largely characterised by violence, loss of government and personal property and, in extreme cases, loss of lives.

The Republic of South Africa is divided into 280 municipalities that constitute the local sphere of government (8 metropolitan municipalities, 44 districts and 228 local municipalities) (SALGA 2017:Online). These municipalities are classified into categories A (metropolitan), B (district) and C (local). These municipalities differ in terms of their capacity to deliver municipal services. These municipalities are either urban (category A) or semi-urban or rural (mainly categories B and C). Urban municipalities have the capacity to attract more qualified employees, whereas rural municipalities have a higher turnover of qualified employees. The inability to retain qualified employees impacts negatively on the ability of municipalities to retain essential skilled employees who are key to improving monitoring and evaluation services.

According to Auditor-General of South Africa (2014:Online), 30 municipalities received clean audits in the 2012-2013 financial year, and 13 of these municipalities sustained their clean audits. Municipalities that received clean audits are good at record keeping and discipline and have strong oversight by mayors and local legislatures. Of the municipalities that were audited in the 2012-2013 financial year, $41 \%$ of the auditees received unqualified opinion with findings, 25\% received a qualified audit opinion, $2 \%$ received an adverse audit opinion and $18 \%$ received disclaimers. A major concern about the audit report is that $90 \%$ of auditees did not comply with laws and regulations. The R11. 6 billion that was classified as irregular expenditure is a consequence of non-compliance with laws and regulations. Twenty-nine auditees ( 1 in the Eastern Cape, 1 in Limpopo, 1 in Mpumalanga, 5 in the Free State, 11 in the Northern Cape and 10 in the North West provinces) received disclaimers for five consecutive years (Auditor-General of South Africa 2014:Online). Tables 1-3 provide a summary of clean audits and disclaimers per province.

Table 1 further provides a clearer picture regarding provinces that are performing well and those that are underperforming. The Western Cape Province has 12 municipalities that received clean audits. This is the highest number in the country followed by KwaZulu-Natal at 7 municipalities.
TABLE 1: Clean audits and persistent disclaimers per province (2012-2013 financial year).

\begin{tabular}{lcc}
\hline Name of province & Clean audit & Persistent disclaimers \\
\hline Eastern Cape & 0 & 1 \\
Free State & 0 & 1 \\
Gauteng & 1 (Sedibeng) & 0 \\
KwaZulu-Natal & 7 & 0 \\
Limpopo & 0 & 1 \\
Mpumalanga & 2 & 1 \\
Northern Cape & 1 & 11 \\
North West & 0 & 10 \\
Western Cape & 12 & 0 \\
\hline
\end{tabular}

Source: Auditor-General of South Africa 2014:Online.

TABLE 2: Clean audits and persistent disclaimers per province (2013-2014 financial year).

\begin{tabular}{lcc}
\hline Name of province & Clean audit & Disclaimers \\
\hline Eastern Cape & 3 & 12 \\
Free State & 0 & 9 \\
Gauteng & 13 & 1 \\
KwaZulu-Natal & 20 & 3 \\
Limpopo & 0 & 6 \\
Mpumalanga & 2 & 4 \\
Northern Cape & 2 & 9 \\
North West & 0 & 8 \\
Western Cape & 18 & 0 \\
\hline
\end{tabular}

Source: Auditor-General of South Africa 2015:Online.

TABLE 3: Clean audits and persistent disclaimers per province (2014-2015 financial year).

\begin{tabular}{lcc}
\hline Name of province & Clean audit & Disclaimers \\
\hline Eastern Cape & 5 & 4 \\
Free State & 1 & 3 \\
Gauteng & 4 & 0 \\
KwaZulu-Natal & 18 & 0 \\
Limpopo & 0 & 5 \\
Mpumalanga & 2 & 4 \\
Northern Cape & 2 & 6 \\
North West & 0 & 6 \\
Western Cape & 22 & 0 \\
\hline
\end{tabular}

Source: Auditor-General of South Africa 2016:Online.

These two provinces do not have municipalities that have received disclaimers in five consecutive years. The figures provided in the three tables indicate which provinces are not performing well. The Northern Cape received only one clean audit and has the highest number of auditees (11) with consistent disclaimers over a period of 5 years. The North West Province is one of the provinces that did not receive clean audits. The number of municipalities in the North West Province that did not receive clean audits is 10 . From a financial audit perspective, it can be inferred that Limpopo and the North West provinces have some of the worst performing municipalities. These two provinces have not been able to register a single clean audit for three consecutive years. These two provinces are also amongst those that must be given preference with regard to capacity building as well as monitoring and evaluation.

The inference made in the above paragraph may be correct from a financial audit perspective. However, a performance audit may reveal a totally different picture. The purpose of any research is not to apportion blame. Research should find 
answers to existing problems. In the case of South African municipalities, the question that needs to be answered is: What can be done to turn the outcomes of negative audits on South African municipalities around? An answer to this question may be that monitoring and evaluation must be improved through training and that more performance audits need to be conducted to give a clearer picture regarding the performance of municipalities. However, simple and quick solutions seldom yield lasting solutions.

South Africa is a unitary state. However, politics and boundaries have turned the country into a pseudo-federal state fraught with localised municipal problems. The Western Cape Province is a province that is under the political leadership of the Democratic Alliance, whereas all the other eight of the nine South African provinces are under the African National Congress (ANC). The Democratic Alliance could claim success in the Western Cape Province, whereas KwaZuluNatal Province may be the only beacon of hope for the ANC. It is in the nature of politicians to bask in the glory of small successes to attract more voters, but in this case the solo beacon under the ANC flagship might be insufficient to recompense.

It is the author's contention that political squabbles and victories should not sidetrack the fact that South Africa is a unitary state. In the broader scheme of municipal governance, an underperforming municipality becomes a burden to the tax payer-cum-voter as well as distorts the best performing municipalities. Municipalities are not businesses and should not be seen to be competing against each other. Instead of competition, there should be more cooperation and sharing of lessons learned from good and bad municipalities. Pairing a well-performing municipality in the Western Cape Province with an underperforming municipality in the North West Province or elsewhere in the country would lead to sharing experiences and best practices. It is the author's contention that a well-performing municipality could also learn from bad practices and avoid falling into the trap of being complacent and repeating the mistakes of other municipalities in future. In the following section, focus is on the capacity of municipal councillors to exercise their oversight roles.

\section{Capacity of councillors to monitor and evaluate performance}

Before one can assess the capacity of councillors regarding their monitoring and evaluation ability, the concept of capacity needs to be explained. Capacity is explained by Koma (2010:115) from three different perspectives, namely the individual, institutional and environmental. Individual capacity is the competency and potential that exist in a person. Institutional capacity takes a macro view of the organisation. It focuses on the organisation's ability and potential from human capital, leadership, infrastructure and financial perspectives, amongst other important factors. Environmental capacity refers to the competence found outside the municipality's formal structures. This includes socio-economic composition of the municipality, political and social capital. Maserumule as cited in Koma (2010:116) is emphatic about the need for politicians and management of municipalities to have the requisite skills, competencies and knowledge. Paradza, Mokwena and Richards (2010:48) argue that councillors who possess low academic and professional qualifications are ill equipped to interrogate officials, critique their work and hold them accountable for their actions and inactions. It is critical for councillors to be able to critically read and analyse reports (Paradza et al 2010:64) and interpret legislation with the requisite fidelity.

African Peer Review Mechanism (2007:79) cited lack of capacity as a challenge facing municipalities in South Africa. A convenient excuse at that time was that local governance structures were still evolving. Disoloane and Lenkonyane (Mpehle \& Kanjere 2013:769) argue that municipalities are likely to fail because of a paucity in capacity, skills and leadership. A study conducted by Mpehle and Kanjere (2013:772) shows that $75 \%$ of respondents do not have a post high school qualification. Only $25 \%$ of councillors have tertiary qualifications, and the inference is that this lack of qualifications ultimately affects the delivery capacity of councillors at the individual level.

Sections 47, 157 and 158 of the Constitution of the Republic of South Africa, 1996 prescribe the criteria for a person to stand for election as a councillor. In terms of Section 47, any South African citizen who is qualified to vote is eligible to be elected as a member of the National Assembly and by extension a member of the provincial legislature as well as a municipal council. Sections 157 and 158 emphasise registration as a voter on the local part of the national voters roll. Although the Constitution, 1996 prescribes the circumstances under which a person may not qualify to stand as a councillor, the supreme law is silent on the qualification that a prospective councillor must have. This silence could be viewed within the context of the Bill of Rights which makes all citizens equal before the law.

A critical argument in this article is whether the right to equality should override quality service which the author submits would be a direct consequence of qualified councillors. A key question that this article attempts to answer is as follows: What should the minimum qualification be for a potential councillor to stand for election? Before answering this question, the requirements for a person to function effectively as a councillor and also discharge his or her monitoring and evaluation responsibilities must be highlighted. The ability to read, understand and write must be a primary requirement. Furthermore, having a critical mind would also come in handy for any councillor to be able to discharge his or her duties. Although the author is tempted to be prescriptive, the Constitution, 1996 overrides any attempt to tamper with the qualification of a person to become a councillor. It is therefore safe to argue that the onus lies with voters to nominate and elect people with a minimum of a Grade 12 or post school qualification. The challenge is getting members of the public to do the right thing. Educating 
the electorate about the quality of candidates appears to be one solution at this stage.

\section{Time as a critical factor in monitoring and evaluation}

A study conducted by Mpehle and Kanjere (2013:772) shows that a corollary to the challenge of capacity is the time that part-time councillors have to do council work. A total of $87.7 \%$ of councillors at Lepelle-Nkupi Local Municipality depend on an annual stipend of approximately R132 000. The remaining councillors have full-time jobs elsewhere. In 2015, part-time councillors' salaries were improved to range between R195 712 and R416 098, whereas full-time councillor's salaries range between R457 210 and R832 197 per annum. Paradza et al. (2010:32) also highlight that councillors in some municipalities took up positions as councillors while they retained their primary jobs. A direct consequence of serving two masters is that these councillors cannot balance their two jobs and they end up not attending some council meetings. If the full-time job salary is higher than the stipend given to a councillor, the loyalty of such a councillor to council work cannot be guaranteed. What complicates matters even further is the unpredictability of politics. The possibility that the councillor may not get a second term suggests that the full-time job provides security and peace of mind that a councillor would not want to lose in the case of any eventuality in his or her political life. From a public choice perspective, it can be argued that self-interest underpins every decision made by politicians.

The time constraints that part-time councillors have to deal with raise the question whether councillors should still be allowed to hold two jobs. Would full-time councillors exercise a better oversight role? Holding two jobs may be avoided if legislation prescribe that all councillors must be full time. Having all councillors focusing on council work on a fulltime basis would require the salary to be improved significantly to be at the level of a provincial member of the legislature. Better salaries would, in the author's opinion, satisfy socio-economic needs of the councillors and their selfinterests. By the same token, municipalities will also be able to attract other professionals out of their jobs to represent communities and make a difference.

\section{Audit committees}

Audit committees are established in terms of Section 166 of the Local Government: Municipal Finance Management Act 2005. Audit committees were from the inception meant to be independent statutory committees with a responsibility to advise the municipal council, councillors, the accounting officer of the municipality and the top management team. Their scope regarding the advisory role includes, amongst others, performance management and evaluation, risk management, good governance as well as matters pertaining to financial control and internal audits. Audit committees are made up of a minimum of three persons who have appropriate experience in municipal administration. The majority of members including the chairperson must not be employed by the municipality. To ensure independence and political neutrality of this committee, councillors are not allowed to be members.

The primary responsibility of municipal audit committees is to maintain, improve standards and enforce financial accountability. George (2005:42) further emphasises the importance of independence and accountability. Dlamini and Migoro (2016:381) believe that to be able to analyse financerelated information, members of audit committees must have sound financial management and related skills. Audit committees' positions are advertised in the media to attract people with relevant skills. Using this analytical framework of public choice theory, the following question can be asked: Are applicants for such positions interested in financial incentives or in contributing to good oversight activities within municipalities? The majority of people who apply do so to augment their incomes. To augment the work done by audit committees, municipal councils can appoint committees that may add value to the improvement of the monitoring and evaluation function performed by councillors. These additional committees of municipal councils envisaged in sections 79 and 80 of the Local Government: Municipal Structures Act 1998 are further discussed in the next section.

\section{Role of public accounts committees}

Municipal Public Accounts Committees (MPACs) are established for each municipality in terms of Section 79 of the Local Government: Municipal Structures Act 117 of 1998. MPACs are statutory committees that differ from the audit committees in terms of their composition. MPACs are made up of councillors who are neither political office-bearers or charged with executive responsibilities. The chairperson of the committee should be a seasoned and experienced councillor who is a member of the ruling or opposition political party. The law does not prescribe the number of members who may serve on each committee. The terms of reference of MPAC are wide-ranging and include the following:

- Unforeseen and unavoidable expenditure

- Unauthorised, irregular, fruitless and wasteful expenditure

- Quarterly report of the mayor

- Monthly budget statements

- Mid-year budget and performance assessments

- Submission and auditing of financial statements

- Submission of annual reports

- Oversight report on annual report

- Issues raised by Auditor-General of South Africa in audit reports

- Disciplinary action

- Audit committee

- Integrated Development Plans

- Performance management plan

- Monitoring of the budget

Paradza et al. (2010:12) argue that municipalities are under no obligation to establish Section 79 committees. Most 
municipalities prefer to establish Section 80 committees that are primarily tasked with the responsibility to support the mayor. These researchers further submit that in municipalities dominated by Section 80 committees, the role of ordinary councillors' oversight is significantly curtailed because of their exclusion from key discussions. The dominance of Section 80 committees further limits municipalities' ability to co-opt experts who are not council members in accordance with Section 79(2) (d) of the Local Government: Municipal Structures Act 1998. It is the author's submission that coopting experts into committees in an advisory capacity may have positive spinoffs on the capacity of municipal councils to monitor and evaluate activities at different operational levels of the municipality.

\section{Effectiveness of Section 139 interventions}

The Constitution, 1996 establishes government on the three spheres, namely the national, provincial and local spheres. The three spheres are distinctive, interrelated and interdependent. The distinctiveness of the spheres is curtailed by the provisions of Section 139 of the Constitution, 1996 which prescribe that the two upper spheres have power to intervene in the affairs of lower spheres if the latter is not capable of fulfilling its constitutional and legislative mandate.

Kahn, Madue and Kalema (2011:8) affirm that there are two schools of thought relating to the concept of interdependence. These two schools of thought are realism and pluralism. Realists are sceptical and do not see any benefits in the interdependence between municipalities and upper spheres of government. Proponents of the pluralism school of thought see some value in interdependence. It is the author's view that municipalities could benefit from interdependence if the monitoring, evaluation and capacity-building functions are performed effectively at national and provincial spheres in relation to activities of municipalities. The failure of a municipality should be construed as the ineptness of provinces to build capacity and exercise the necessary oversight to avoid possible interventions.

From the foregoing argument, an assertion is made that interventions are ineffective without capacity building. This assertion is supported by Thornhill and Cloete (2014:52) who recognise that interventions are ex post; hence, they are unable to prevent ineffective administration. Any intervention should be preceded by effective monitoring, evaluation and capacity building of councillors and officials. Interventions should only be considered when all efforts have failed but before service delivery standards are compromised to the detriment of communities and the municipality is no longer functional from a financial perspective.

Interventions in a municipality may take place in terms of Section 139(1) (a), (b) or (c) of the Constitution, 1996. Section 139(1) (a) of the Constitution, 1996 provides that intervention involves the issuing of a directive by the province to the local legislature. This type of intervention can be classified as a pseudo intervention. The directive must describe the nature of failure and then propose action that is necessary to rectify the existing or alleged anomaly. Intervention in terms of subsection 1(b) of the Constitution, 1996 involves taking the responsibility to fulfil the mandate of the municipality. This type of intervention was applied at Ditsobotla, Matlosana and Maquassi Hills local municipalities without achieving the desired results (Section 139(1) (B) of the Constitution, 1996 interventions in Maquassi Hills Municipality, 2015:Online). The third type of intervention invokes subsection 1(c) of the Constitution, 1996. Invoking this subsection leads to the dissolution of a municipal council and replacing it with an administrator until the election of a new council. This type of intervention is rarely applied and is only necessary in exceptional circumstances where a municipality cannot deliver services and fails to approve its budget.

It is the author's contention that not all interventions have been successful. There are municipalities in South Africa that have been under different interventions as outlined above. These municipalities, after more than one interventions, still need to be in 'intensive care' because they barely meet the minimum requirements of their obligations. It is therefore not surprising to see an increasing number of service delivery protests in South Africa. The failure of interventions could be ascribed to the lack of monitoring and evaluation of interventions and transitions when appointed administrators leave after interventions.

\section{Conclusions}

This article has probed the role of monitoring and evaluation at a political level. From the arguments advanced in this article, it could be inferred that some municipalities in South Africa are not effectively fulfilling their constitutional mandates. The failure of municipalities to fulfil their constitutional mandates is primarily because of the incapacity of councillors, ineffective interventions, ineffective monitoring of interventions and poor management of transitions after interventions, as well as outright avoidance of interventions for political expedience. Intervention of the ruling party in a province in the affairs of an ailing municipality controlled by the same party may be seen as an admission of failure. Consequently, municipalities that should be put under administration are not simply because political parties may want to 'look good' in the eyes of the electorate and other political parties. The result of this situation is the chronic underperformance of some municipalities. The article has provided a macro perspective on challenges relating to the monitoring and evaluation of performance in South African municipalities. It is suggested that future research focus on individual underperforming municipalities.

\section{Recommendations}

A number of suggestions have already been made in the article regarding the solutions to some of the monitoring 
and evaluation challenges. The following are consolidated recommendations:

- Communities need to be educated about the nomination and election of councillors who are literate and can make a contribution to the monitoring and evaluation functions performed by municipalities.

- Councillor's remuneration must be improved and legislation with regard their election ought to change to have full-time councillors.

- Departments responsible for local government in each province must link best performing municipalities with underperforming municipalities. The suggested linkage could take the form of monthly political and technical meetings or workshops in areas where weaker municipalities are not performing well. These meetings or workshops can become catalysts in the sharing of variety of knowledge and skills relating to monitoring and evaluation functions.

- Monitoring and evaluation of interventions must be strengthened by appointing people who would leave a functional municipality not dependent on their skills.

- Education and training of councillors must be prioritised by all municipalities.

\section{Acknowledgements Competing interests}

The author declares that he has no financial or personal relationships which may have inappropriately influenced him in writing this article.

\section{References}

African Peer Review Mechanism (APRM), 2007, Country Review report no 5, Republic of South Africa, NEPAD, Midrand.

Auditor-General of South Africa, 2014, 2012-2013 MFMA Consolidated general report, viewed 30 May 2017, from http://www.agsa.org.za

Auditor-General of South Africa, 2015, 2013-2014 MFMA Consolidated genera report, viewed 30 May 2017, from http://www.agsa.org.za

Auditor-General of South Africa, 2016, 2014-2015 MFMA Consolidated general report, viewed 30 May 2017, from http://www.agsa.org.za

Bana, B.A., 2014, 'Regulatory and oversight systems for revitalizing public administrations systems in Africa', Journal of Public Administration 49(2.1) 637-652.

Dlamini, P.C. \& Migoro, S.O., 2016, 'Performance monitoring and evaluation systems in the South African Local Government', Journal of Public Administration 51(3), 376-390.

George, N., 2005, 'The role of audit committees in the public sector', The CPA Journa $75(8), 42-43$.

Govender, I.G. \& Reddy, P.S., 2014, 'Monitoring and evaluation in municipalities: A case of KwaZulu-Natal Province', Administratio Publica 22(4), 160-177.

Kahn, S., Madue, S.M. \& Kalema, R., 2011, Intergovernmental relations in South Africa, Government Printer, Pretoria.

Koma, S.B., 2010, 'The state of local government in South Africa: Issues, trends and options', Journal of Public Administration 45(1.1), 111-120.

Mpehle, Z. \& Kanjere, M., 2013, 'Empowering women councilors through leadership development programme', Journal of Public Administration 48(4.1), 764-776.

Paradza, G., Mokwena, L. \& Richards, R., 2010, Assessing the role of councilors in service delivery at local government level in South Africa: Report 125, Centre for Policy Studies, Johannesburg.

SALGA, 2017, About municipalities, viewed 07 June 2017, from https://www.salga. org.za

Saunders, M., Lewis, P. \& Thornhill, A., 2009, Research methods for business students, 5 th edn., Prentice Hall, Harlow.

Section 139 (1) (B) interventions in Maquassi Hills Municipality, viewed 27 May 2017 from http://www.gov.za-1391-b-intervention

Republic of South Africa, 1996, Constitution of the Republic of South Africa, 1996, Government Printers, Pretoria.

Republic of South Africa, 1998, Local Government: Municipal Structures Act 117 of 1998, Government Printers, Pretoria.

Thornhill, C. \& Cloete, J.J.N., 2014, South African municipal Government Administration, 2nd edn., Van Schaik, Pretoria. 